可撓中空導光路のパルス $\mathrm{CO}_{2}$ レーザー伝送

\author{
Flexible Hollow Light Guide \\ for Higher Peak Short Pulse $\mathrm{CO}_{2}$ Laser \\ 橋新裕一・ 冫保宇市
}

Yuichi HASHISHIN and Uichi KUBO

近畿大学理工学部電気工学科

Kinki University

\begin{abstract}
We have developed a fiexible $\mathrm{CO}_{2}$ laser beam guide with metal and polymer compound hollow tube. In this paper, it was concentrated the research which the higher peak short pulse $\mathrm{CO}_{2}$ laser beam transmission. The characteristics of incident beam is $500 \mathrm{~kW}$ peak pulse power, $80 \mathrm{~ns}$ pulse width and $10 \mathrm{~Hz}$ repeat pulse. One pulse energy is ca. $40 \mathrm{~mJ}$. From the experimental result, the pulse beam transmittance was obtained ca.90 \%/m at straight shape power, $36 \mathrm{~mJ}$ per pulse. In the bent shape tube with bending radius $\mathrm{ca} .15 \mathrm{~cm}$, transmittance is ca. $80 \% / \mathrm{m}$, pulse shape is not change almost.

In this results, it was clarified that the hollow guide tube is useful flexible guide tube for higher pulse power $\mathrm{CO}_{2}$ laser transmission.
\end{abstract}

1.はじめに

最近, 我々は $\mathrm{C} \mathrm{O}_{2}$ レーザーでも高尖頭值短パ ルス化によって炭化を伴わない切開が可能である てとを見出した。この利点を生かしてバルスレー ザーの新しい応用が考えられ, 高尖頭俌短バルス
$\mathrm{CO}_{2}$ レーザーの導光系が必装である。彷来, 中 空導光路の連続発振 $\mathrm{C} \mathrm{O}_{2}$ レーザー伝送特性を調 ベてきだ,2)が, 今回は高尖頭值短バルスのTEA$\mathrm{C} \mathrm{O}_{2}$ レーザーの中空導光路伝送特性を楛べた。 


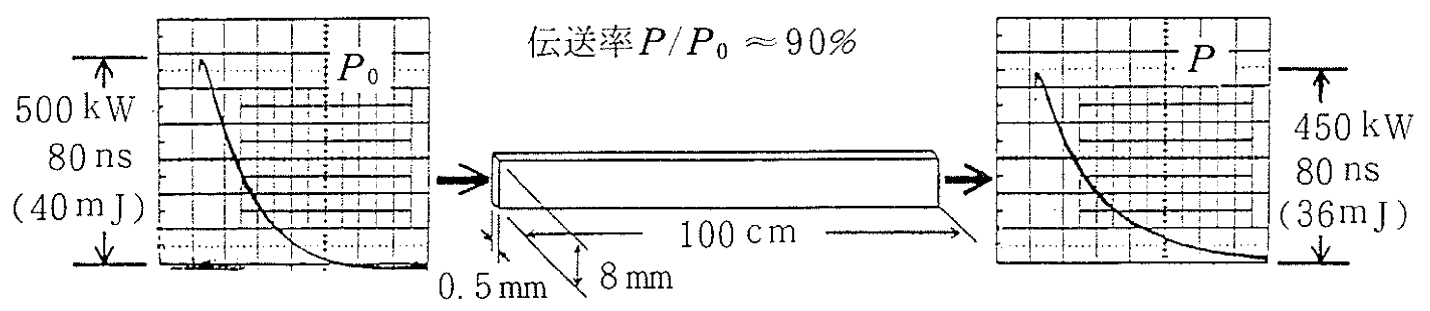

図 1 直線状態の伝送特性

\section{2. 実験装置及び方法}

使用した繰返しパルス $\mathrm{CO}_{2}$ レーザーのパルス尖䫒值は $500 \mathrm{~kW}$ ，パルス幅は約 80 $\mathrm{ns}, 1$ パルスのエネルギー

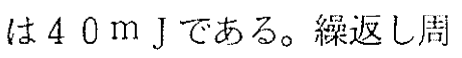
波数は最大 $10 \mathrm{~Hz}$, レーザ ービームは $20 \times 15 \mathrm{mmb}$ 矩形状である。中空導光路の 構造は従来報告したもの上同 じである。镈光路断闻の寸法 は長辺 $8 \mathrm{~mm}$, 短辺 $0.5 \mathrm{~mm}$, 長さは $1 \mathrm{~m}$ である 実験は中空導光路の直線状態, 曲げ状態の伝送特 性索調べた。

\section{3. 直線状態での伝送特性}

得られた放射パルスの尖頭值は $450 \mathrm{~kW}$ ，パル ス幅は $80 \mathrm{n} \mathrm{s}, 1$ パルスのエネルギーは $36 \mathrm{~m} \mathrm{~J}$ で，伍送率は長さ 1 mで約 $90 \%$ であった（网1）。

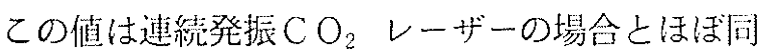
じで值である。また，長さ $1 \mathrm{~m}$ 门中空導光路中を 伝送された放射パルス波形は入射バルス波形とほ とんど变わらず，波非の乱れ，パルス幅の搪がり は生じなかった。入射ビームの横モードは矩形状 のゼブラモードであるが，放射ビームは台形状ひ 均一化された溞度分布走もつ。入射パワ一密度は 約 $16 \mathrm{MW} / \mathrm{cm}^{2}\left(1.3 \mathrm{~J} / \mathrm{cm}^{2}\right)$ の高バワー密度であ るが，導光路の入射部に異常は起こらず，更に高 出力のパルスレーザー伝送む可能である。放射ビ 一ムを罒柱状レンズと円レンズで集光して得られ

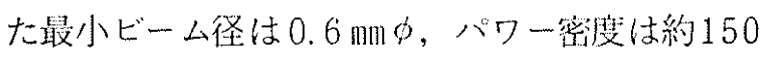
$\mathrm{MW} / \mathrm{cm}^{2}\left(12 \mathrm{~J} / \mathrm{cm}^{2} \cdot\right.$ pulse $)$ に達した。

伝送摔 $P / P_{0} \approx 80 \%$

長さ： $100 \mathrm{~cm}$

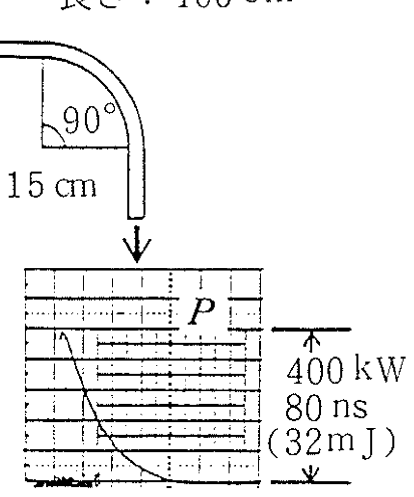

図 2 曲げ状態の伝送特性

\section{4. 曲げ状態での伝送特性}

曲げ半径 $15 \mathrm{~cm}$, 曲げ角度 $90^{\circ}$ の曲げ状態で 伝送特性を調べた。長さ $1 \mathrm{~m}$ 心場合の結果を図 2 に示した。戍のごとく，得られた放射パルスの尖 頭优は $400 \mathrm{~kW}$ ，パルス幅は $80 \mathrm{~ns}, 1$ パルスの

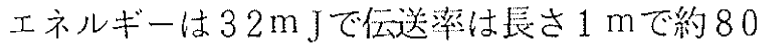
\%であった。この値も連続発振 $\mathrm{C} \mathrm{O}_{2}$ レーザーの 場合と同じ值であった。この状態で繰返し周波数 $10 \mathrm{~Hz}$, 約 15 分（約 10,000パルス)0連続伝 送で屯導光路に買常は認められず，更に長時間の 伝送む可能である。

\section{5. 結諭}

試作した中空導光路は高尖頭値短パルス $\mathrm{C} \mathrm{O}_{2}$ レーザーに対しても連続発振 $\mathrm{C} \mathrm{O}_{2}$ レーザーの場 合と同様に使用し得ることが明らがなった。

文献

1）久保，橋新：日本レーザー医学会誌，Vol.6, No. 3, P.359 (1986)

2）橋新, 久保：日本レーザー医学会誌，Vol. 7, No. 3, P.161 (1987) 